\title{
Correction to: Characterization of Mode I and Mode II traction-separation laws for cohesive separation of uncured thermoset tows
}

\author{
Sreehari Rajan - Michael A. Sutton - William McMakin • Elsa Compton • \\ Addis Kidane · Zafer Gurdal · Roudy Wehbe · Farzana Yasmeen
}

Published online: 3 February 2020

(C) Springer Nature B.V. 2020

\section{Correction to: \\ Int J Fract \\ https://doi.org/10.1007/s10704-019-00399-1}

This article was published with an erroneous author name. Please find on this page the correct version of the author name that should be regarded as the final version by the reader.
The online version of the original article can be found under https://doi.org/10.1007/s10704-019-00399-1.

S. Rajan · M. A. Sutton (凶) . W. McMakin · E. Compton · A. Kidane $\cdot$ Z. Gurdal $\cdot$ R. Wehbe $\cdot$ F. Yasmeen McNair Aerospace Center and Department of Mechanical Engineering, University of South Carolina, Columbia, SC 29208, USA

e-mail: sutton@sc.edu
Publisher's Note Springer Nature remains neutral with regard to jurisdictional claims in published maps and institutional affiliations. 